The Society of Medical Officers of Health.

\begin{tabular}{|c|c|}
\hline No. 3. & $\mathrm{DECE}$ \\
\hline COUNTY & HEALTH . ADMINISTRATION." \\
\hline & $\begin{array}{l}\text { BY WDWAID SEILGEANT. } \\
\text { M.R.C.S., L.R.C.P., L.S.Sc. }\end{array}$ \\
\hline Medical & $\begin{array}{l}\text { Officer of Health to the Lancashire } \\
\text { County Council. }\end{array}$ \\
\hline
\end{tabular}
Health, you have conferred an honour which I am bound to appreciate to the fullest extent, more especially as the possibility of occupying such a distinguished position never came within the purview of my ambition during the many years I have been a humble labourer in the field of sanitation. I thank you most sincerely for the confidence you have reposed in me, and also for the compliment you have indirectly paid to the branch of the Society to which I belong. The responsibilityI will not say penalty - attached to my high office of having to deliver an inaugural address, is like the fly in the amber, and occasions a sense of alarm at the difficulties I have to encounter, and a feeling that

"So mighty and so many my defects,

As I had rather hide me from my greatness."

My brilliant predecessors have made it hard for me to follow in their footsteps; but I assure you, that during my occupation of the Presidential Chair, I will spare no effort to carry out the important duties of my office in accord with its best traditions.

I have experienced some hesitation in selecting a subject for my address, but when we consider the unusual amount of sanitary legislation now in progress, and the interest taken by all sorts and conditions of men in matters relating to the health of the people, there really ought to be no difficulty in finding a suitable theme. The position a medical officer holds in regard to the health administration of a large county, affords him. ample scope for the discussion of matters of sanitary importance which may be worthy of your consideration, and not threadbare from much usage.

* Presidential Address delivered at the Meeting of the Society on November 13 th, 1908.
Evolution of the Medical Officen
ur Illahiti.

In tracing the evolution of a medical ollicer of health, it is well to remember that he limet came into being so far back as 1847 , wlen 1 , tho Towns Improvement Clauses Act, Sectivi XII., it was enated that the commissionses of any local district may, "if they think fit," appoint a person of competent skill and experience who shall be styled "The Officer of Health," whose duty it shall be to ascertain the existence of diseases, "especially epiclemics and contagious diseases, and to point out any nuisances or other local causes likely to cause and continue such diseases or otherwise injure the health of the inhabitants, and to point out the best means for checking or preventing the spread of such diseases. . . and also the best means for the ventilation of churches, chapels, schools, registered lodging houses and other public buildings." It may be observed that the appointment was apparently of a tentative character, the expediency for which was open to some doubt. There was no intention that the health officer should necessarily belong to the medical profession, although there would be some of his duties which could be most satisfactorily discharged by any ordinary practitioner, but as a public prosecutor against unwholesome influences removable under the sanitary law, he would be required to exercise functions of a quasi-judicial character. Such an appointment could be most suitably filled by a person entirely engaged in the public health service either by a large sanitary authority or combination of authorities. In the Public Health Act of the following year, although the appointment still remained permissive, it was now provided that the officer should be a "legally qualified medical practitioner," while after a long period of probation a further phase was attained by the Public Health Act, 1872, which made it compulsory for each of the newly created urban and rural sanitary authorities to appoint an official known for the first time as the Medical Officer of Health. 
In framing the Local Government Act, 1888, by which the general plan of Local Government for England was so importantly auginented, Parliament again acted tentatirely, in merely authorising county councils " if they see fit" to appoint a medical officer of health; and it is, I presume, partly in consequence of some of the smaller county councils not having taken advantage of this power of appointment, and partly due to the important sanitary duties imposed on them by the Education (Administrative Provisions) Act, 1907, that the Government in the Housing, Town Planning, \&c., Bill now before Parliament, have introduced a clause making it incumbent on every county council to appoint a medical officer of health. Instead of simply requiring a medical officer of health to be a "qualified medical practitioner," Section 18 of the Local Government Act, 1888 , provides, that in future every one appointed as medical officer of health, must possess an all-round legal qualification in medicine, surgery and midwifery, and the same section contains a far-reaching proviso that, after January 1st, 1892, no person shall be appointed medical officer of health to a county or sanitary district-urban or rural-having a population of 50,000 or upwards, unless he holds in addition a diploma in sanitary science, public health or state medicine, or has served as medical officer of health under certain specified conditions previous to the passing of the Act.

\section{County ADMinistration.}

The power given by the Local Government Act, Sec. 17 (2) to the county council for rendering the services of their medical officer of health available in county districts, indicated apparently a desire on the part of legislature to enlarge the area for direct administrative control, and possibly secure greater efficiency with, at the same time, more economy. With one exception, Worcestershire, * this provision in the Act did not meet with the approval of district councils, who, as a rule, prefer to control their own officials, and county councils were not able or desirous of offering them any inducement to give up their freedom of action. 'The proposal for grouping and consolidating districts in a large county for sanitary purposes, even if advisable, would be extremely difficult, and would be met with great opposition from district representatives and from those now holding office, unless it was at the same time accompanied by proper compensation.

\footnotetext{
* Essex, Gloncestershire and Warwick shire are also exceptions but in these counties the medical officers of health, when appointed, held medical officerships and were allowed to continue them. In Herts, sueh a combination was not allowed by the Iocal Government Board in 1901 between the County Council and District Authority was allowed.
}

I believe it is far better for district authorities, in combination if possible, to be entirely responsible for their own sanitary government, with the assistance and advice of the county medical officer available when required. The latter, as an official of the county and independent of local considerations will, in $m y$ opinion, be more competent to carry ont impartially his supervisory functions, and tender advice to the county council as to any shorteomings in their administrative area. The view of the present Government as to the utility of the scheme originally foreshadowed, is shown by the introduction of a clause in the Housing, Town Planning, etc., Bill, which provides for the withdrawal of this power on the part of the county and district councils for arranging with respect to the joint services of a medical officer of health.

The council of each county have an important obligation imposed on them to pay out of the Exchequer Contribution Account to every local authority one-half the salary of their medical officer of health, providing the appointment, salary and tenure of office "are in accordance with the Public Health Act, 1875 , or any Act repealed by that Act." But it is also provided that no payment shall be made "if the Local Government Board certify to the council that such officer has failed to sencl to the Local Government Board such reports and returns as are for the time being required by the regulations respecting the duties of such officer." You will observe that county councils are merely required under certain specified conditions to make contributions to salaries, but they have no authority whatever in the making of the appointments or providing for the tenure of office, nor can they extend support to an official who may happen to be penalised for excess of zeal displayed in the carrying out of his public duties. Even the Local Government Board seem to be powerless when, as occasionally happens, district councils refuse to re-elect a medical officer of health at the conclusion of his period of office, although he may have conducted himself sans peur et sans reproche. Cases of great hardship might have been prevented if the Board had possessed the power of intervention, or if the recommendation of the Royal Sanitary Commission, made so far back as 1869, had become law, to the effect that a medical officer of health "should not be removable from office by any local authority except with the sanction of the central authority." The smaller, and a few of the whole-time appointments, are limited to one year, but they occasionally extend over two, three, or five years. Sir Walter Foster, Parliamentary Secretary to the Iocal Govern- 
ment Board, in 1895, stated that "the Board had arrived at a rather important decision, viz., that we consider these appointments for short periods and precarious tenure injurious to the public health. . . Men holding. appointments for very limited periods cannot be expected to discharge their duties in that fearless and thorough manner which those duties require for the safety of the public, and we are anxious to encourage local authorities to give up the system of short appointments." The Board, about that time I beliere, intimated to local authorities that under certain conditions appointments might, with advantage, be made for longer periods, and, if possible, permanent, i.e., during good behaviour; but judging by the districts of the county with which I have the honour of being connected, their advice did not receive the attention it deserved.

Although the question of salary is not one often discussed at our meetings, it has some bearing on the amount of work expected to be carried out by a medical officer of health, and indicates the importance of that work in the eyes of the authority which he serves. For some years, I am happy to say, the Local Government Board have tried to influence local authorities, especially the larger ones, in the direction of paying adequate salaries; but in many of the smaller sanitary districts not more than $£ 20$ to $£ 30$ per annum is still considered sufficient remuneration for the carrying out by the medical officer of health of his ever-increasing duties. Such salaries are too paltry even in the smallest districts for the conscientious performance of high-class professional services relating to sanitation, preparation of statistics, and other matters which have to be reported on periodically, and form annually the subject of an elaborate report.

A district medical officer of health has an important duty to observe in relation to county councils on which is based much of the county sanitary work; under Sec. 19 of the Local Government Act, it is necessary for him to supply the county council with a copy of every periodical report, including, of course, his annual report, prepared in conformity with the regulations of the Local Government Board; and "if a medical officer of health fails to send such copy, the county council may refuse to pay any contribution, which otherwise the council would, in pursuance of the Act, pay towards the salary of such medical officer." In addition, the regulations of the Board in 1891, respecting the duties of an urban or rural medical officer of health, require him to transmit to the county council, a copy of any report he may make to the Local Government Board on any outbreak of infectious disease, or of any matter, such as school closure, which may form the subject of a special reprort. On the county medical officer devolves the duty of collating these reports for the information of his council, and if it appears from any report that the P'ublic Health Act, 1875, has not been properly put in force in any district, or that any matter affecting the public health of a district requires to be remedied, the council may cause a representation to be made to the Local Government Board. This would probably be made under the Public Health Act, $187 \overline{0}$, Sec. 299 , and the Tocal Government Board, if satisficd after due inquiry of the alleged default, may make an order on the local authority for the performance of their duty, or appoint a person to perform the duty and recover the expenses from the local authority. Similar powers can now be exercised by the county council under the Local Government Act, 189) 4 , Sec. 16, in case of default in sanitary administration by a rural district council; the parish council may complain to the county council, and, if after inquiry the county council are satisfied that there has been a failure as regards the subject-matter of the complaint, they may resolve that the duties of the district council for this purpose shall be transferred to them. On no occasion has the Lancashire County Council made a statutory complaint to the Local Government Board, under Section 299 already mentioned, respecting any district authority, as, I am glad to say, it has been found sufficient and more expeditious to communicate directly with the districts in default. I may also state that it is only on very rare occasions that parish councils appeal to the county authority in regard to sanitary neglect in rural districts.

The county council, by becoming possessed of the reports periodically issued by district inedical officers of health, are enabled to compile valuable vital statistics, and obtain information concerning sanitary matters which, for comparative purposes, are much appreciated. The annual reports issued by medical officers of health are prepared with greater care and uniformity than formerly, when they merely attained the distinction of being pigeon-holed in the district offices. Useful information is now given by the medical officer of health, in accordance with the regulations of the Local Government Board, as to the action his authority has taken, or been advised to take, for preventing the spread of disease, and with respect to the sanitary supervision over the places and houses that 
the local anthority have to regulate, together with the nature and results of any proceedings which may have been necessitated. The report is also required to contain a record of the action taken in regard to offensive trades, to dairies, cowsheds, and milkshops, and to factories and workshops. Other information regarding water supply, scavenging, sanitary supervision of elementary schools, and any matters of sanitary interest are, as a rule, referred to in the report, and subjected to criticism in the annual digest of the county medical officer of health. In districts where sanitary matters receive insufficient attention, it is accepted as the duty of the supervisory authority-although not specified by Act of Parliament--to stimulate and encourage the lagging footsteps of local bodies, and it is interesting to observe how much a little tactful advice will accomplish. Local medical officers of health have invariably given me the fullest information on any subject appertaining to their districts, and to their credit, I may mention that monthly returns are voluntarily supplied to the county with reference to deaths and infectious disease; and, since the passing of the Midwives' Act, particulars respecting cases of puerperal fever are reported to me immediately after notification.

It was intended, as doubtless you are aware, when the Local Government Act was before Parliament, that county councils should be given direct controlling power over sanitary matters in the districts within their administrative areas, either on local complaint or on their own initiative ; and later in the Session of 1889, Mr. Ritchie introduced a Provisional Order Bill, which contained proposals for transferring to county councils a variety of central powers, which, if carried out, would practically have meant the substitution of the county council for the Local Government Board as authority of control, although it was not proposed to transfer, as was intended by decentralising schedule of 1888, the important powers given to the Local Government Board by Section 299 of the Public Health Act. District councils and non-county boroughs throughout the country strongly resented the proposal that they should be made subject, as regards their sanitary administration to the county authorities, and, owing to this opposition, Mr. Ritchie's Bill was not proceeded with. As I have already mentioned, district councils in Lancashire have, with few exceptions, shown an earnest desire to carry ont their public duties, and judicious advice has been well received; but there is still much to be expected from the "coerciveness of knowledge and public conscience."*"

\section{Pollution of Rivers.}

Another work given to county councils on their formation relates to the pollution of rivers, and no one will deny that it has been carried out conscientiously and proved of immense sanitary value. By Section 14 of the Local Government Act, a county council is authorised to enforce the provisions of the Rivers Pollution Prevention Act in regard to streams which belong to the county or pass through, or by any part of its area " as if they were a sanitary authority within the meaning of that Act." I may observe that for a period of twelve years, no serious action was taken by sanitary authorities against polluters, and the Act passed in 1876, remained practically inoperative, and was spoken of as " utterly unworkable and useless," an opinion based on the experience of a few public authorities who had initiated proceedings under the Act in a faint-hearted and perfunctory manner. When county councils and the more powerful joint committees, created under Section 14, Sub-section 3 of the Local Government Act commenced their work, it was recognised that sanitary authorities would have to deal effectually with their sewage, and that polluting trade effuents would not be allowed to enter streams as heretofore. At the commencement of the new régime, manufacturers were soon up in arms, and even public bodies refrained from taking action until a few successful prosecutions showed that no one, however powerful, could escape-in Lancashire at any ratefrom the operation of the Act. The joint committees already referred to have supervision of very wide areas, and the constituent authorities comprise administrative counties and county boroughs. I have knowledge of the three watershed committees constituted, viz., the Mersey and Irwell Joint, the Ribble Joint, and the West Riding of Yorkshire Rivers Board. The first two were created in 1891, after Local Government Board inquiries, and the latter came into existence in 1893. These committees, composed of members representative of the whole area under their jurisdiction, carry out their functions, I believe,

\footnotetext{
* English Sanitary Institutions, Sir John Simon.
} 
more economically and efficiently in their joint capacity than as separate authorities, and it is difficult to explain why so few combinations of this kind have been formed in the large manufacturing centres of the country. * It should be thoroughly understood that these joint committees were only given the powers already possessed by urban and rural sanitary authorities, and such powers are exercisable concurrently without any abolition or curtailment of local control. But experience shows that when joint committees commenced their operations, they so completely carried out their duties, that sanitary authorities ceased to act. The Mersey and Irwell Committee represents a powerful combination possessed of ample means for enforcing authoritatively due observance of the law relating to pollution. It comprises portions of three administrative connties of Lancashire, Cheshire and Derbyshire, the important City of Manchester, and the county boroughs of Salford, Oldham, Bolton, Rochdale, Bury and Stockport. The following is a summary of the area, population and rateable value of this watershed as recently estimated :-

\begin{tabular}{|c|c|c|c|}
\hline & $\begin{array}{l}\text { Acreage } \\
\text { at } \\
\text { Formation. }\end{array}$ & $\begin{array}{l}\text { Fstimated } \\
\text { Population. }\end{array}$ & $\begin{array}{l}\text { Rateable } \\
\text { Value. }\end{array}$ \\
\hline Lancashire $\ldots . \quad \ldots$ & 262,718 & 846,606 & $3,778,549$ \\
\hline ., County Boroughs & 32,656 & $1,347,420$ & $7,176,427$ \\
\hline Cheshire $\quad \ldots \quad \ldots$ & 250,348 & 276,073 & $1,495,924$ \\
\hline , Stockport (C.B.) & 2,200 & 102,340 & 430,051 \\
\hline \multirow[t]{2}{*}{ Derbyshire ... ... } & 20,781 & 53,371 & 285,044 \\
\hline & 568,703 & $2,625,810$ & $13,165,995$ \\
\hline
\end{tabular}

The joint committee of the Ribble watershed is composed of representatives of the administrative county of Lancashire, and the county boroughs of Blackburn, Burnley, Preston and Wigan; the drainage area, comprising 368,640 acres, is under their jurisdiction, with a population estimated at the last census at $1,122,864$, and a rateable value in 1905 , of $£ 4,168,220$. The watershed under the supervision of the West Riding of Yorkshire Rivers Board is a very extensive one, embracing the administrative county of the West Riding, the cities of Leeds; Sheffield and Bradford, and the county boroughs of Halifax, Huddersfield and Rotherham; altogether an area of $1,773,366$ acres, with a population estimated at $3,004,662$, and a rateable value of $\mathfrak{1 4}, 549,122$.

When these committees came into being,

* I find that the Royal Commission on Sewage Disposal (Third Report, 1903), recemmend that River Boards should be formed for other parts of the country, similar to the three which exist in Lancashire and Yorkshire. many of the large towns were accustomed to treat their sewage, but only exceptionally was the effluent sufficiently purified to allow of its entrance to a river without cansing serious pollution. Of the forty-one towns in the Mersey and Irwell watershed, eighteen were entirely without any means of dealing with sewage, and their systems of sewerage were more or less imperfect. Urban authorities in a few instances treated their sewage, but it was stated at the Local Government Board inquiries, re the formation of joint committees in Lancashire, that even where works existed they were only used on "show" occasions, or" during "certain times of the clay," and the storm-overflows at the works were so arranged as to allow large volumes of sewage to pass continuously into the rivers untreated. When a flood occurred, offensive deposits were washed from the sewers or from the bed of the stream on which it had accumulated, and the various impurities, both in suspension and solution, were so concentrated as to poison or suffocate fish wholesale. The Ribble, which at one time had great repute for its salmon, and is, I believe, once more regaining it, was occasionally affected to a serious extent, and I have myself seen tons of fish destroyed in this way floating down the river.* The late Frank Buckland observed that a fish poisoned by pollution, as a rule died "with the gills and mouth widely extended as if gasping for breath." Damage due to sewage deposit was also done to the spawning beds, while the destruction of weeds and insect life forming the food of fish further aggravated the evil.

The principal sources of river pollution by manufacturing refuse within the Mersey and Ribble basins are derived from dye, print, and bleach-works, chemical works, tanneries, paper making, woollen works and silk works. These trade pollutions are amenable to chemical and mechanical remedies, which may be applied without interfering with the manufacturing interests, and as "necessity is the mother of invention" certain processes are now available for dealing profitably with many of the by-products. As a few instances, I may mention the employment of the "Magma" process for recovering crude oil from the soapsuds used in dying operations and wool washing. In the indigo dyeing trade the spent vat liquors and wash waters,

\footnotetext{
* The rivers Eden, Lune and Dee, on the west coast, liave also been seriously affected by sewage deposit, (See Report of Royal Commission on Sewage Disposal, Appendix VI.)
} 
after settlement, give a sludge containing so much indigo that it can be profitably re-used. In the paper trade, the strong alkali liquors obtained by boiling esparto grass with alkali, and which at one time were a source of gross pollution, are now evaporated, burnt, and the soda present in the resultant ash practically repays the cost of treatment. The waste waters from the paper machines also give sludge which is of considerable value. Mr. Halliwell, chief inspector of the Ribble Watershed Committee, informs me that a paper manufacturer, against whom an order was obtained for turning the sludge from the settling tanks into the river, has found his sludge to be of such value for paper making, that he is able by its use to effect a saving in raw material amounting to over $£ 1,000$ per annum. In the manufacture of soap, the spent lees are concentrated and distilled, and the glycerine, which at one time was turned into the river, is recovered; and, as a further example of saving, may be mentioned the recovery and conversion into coke of the sludge deposited in coal washing, which formerly was passed into the streams and formed a serious pollution.

One of my first duties as county medical officer required me to make an inspection of the rivers of Lancashire in regard to their state of pollution, and I had occasion to point out that many of them were more or less silted up by solid matter in the form of ashes from manufactories, household refuse (including the contents of ashpits), etc. Foul emanations were given off during the process of decomposition, which proved distinctly offensive and possibly injurious to the health of persons living in the vicinity. This form of solid pollution, I am glad to say, received immediate attention on the formation of the joint cominittees, and only a very short time elapsed before the nuisance ceased, although the injurious effects of the refuse deposited on the beds of the rivers may still be seen. The methods adopted by towns and urban districts in dealing with their sewage also soon came under the notice of the joint committees, and owing to the firm pressure applied, there is not one authority within their jurisdiction now without effective means of treatment. Careful supervision is exercised over the various sewage works in operation, and samples are taken periodically to see that the sewage continues to receive reasonable and proper purification. The same may be said of the trade effuents which are generally dealt with on approved methods, and I believe without injury to the commercial interests involved." The vast amount of work carried out by the joint committees and by many of the county councils, has been enormously expensive, but without doubt it has proved entirely beneficial, and of immense sanitary value, and those who have in any way rendered assistance deserve the greatest credit.

\section{Poliution of Esturial and Tidal Waters.}

Although much has been done to improve the condition of our rivers, there.still remains to be dealt with the tidal waters (esturial and other), and foreshores of a large portion of Great Britain, which receive serious pollution from the improper discharge of untreated sewage. For some years past shell fish (oysters, cockles and mussels) gathered from sources exposed to sewage contamination have been reeognised as the canse of numerous well-known outbreaks of enteric fever, and shell fish, however slightly contaminated, more especially when eaten raw, cannot be looked upon as free from danger. The extent of the danger is great as regards Lancashire, for very few, if any, of the mussel or cockle beds can be said to be outside the "sewage zone" or uninfluenced by the polluting esturial waters. Bacteriological investigations by Professor Herdman have shown the presence of the $B$. coli in practically all the mussels taken from the Lancashire coast; the sewage micro-organisms not being so frequently found in cockles, as apparently they have the power of cleaning themselves more readily than mussels (Klein). As the - B. coli is not found in unpolluted salt water fish, its presence must be regarded with suspicion, and as evidence that the shell fish has lived in the sea water contaminated with sewage. It always indicates " the possibility that the shell fish in which it is found may, under certain circumstances, come to harbour microbes of a nature strictly pathogenic, such as the typhoid bacillus, but when the number of $B$. coli in a mussel is few, then this possibility is remote. $† "$ Only a few instances are recorded of the $B$. typhosus having been isolated from shell fish, but there is reason to

*1)r. 'Thresh in his County Annual Report for 1907 , says that " the gross pollution of the Essex rivers, which was not uncommon some ten years ágo, is now a thing of the past. All the towns of any size liave provided sewage works, and the efluent now discharged, though not always what it mi,ght be, is very different to crude sewage."

$\dagger$ theport (1906) in connection with the Tancashire and Western Sea Fisheries, by Professor Herdman, assisted by Mr. James Johnstone. 
believe that it is not infrequently present. The investigations of Sir Rubert Boyce and Professor Herdman also show the inimical effect of sea-water on the growth of the typhoid bacillus:; it is also interesting to observe that the organism does not increase in the body or in the tissues of the oyster, and that it perishes in the intestine. Its presence indicates recent and therefore dangerous pollution if accompanied by large number's of $B$. coli. The vitality of the typhoid bacillus in sea water and in water of different degrees of salinity has an important bearing upon the question of risks of specific pollutiont, and in respect of oysters, Dr. Klein believes "that there is no such immediate disinfectant action possessed by sea-water as was formerly assumed, and that, therefore, persons who place oysters near to sewage outfalls in this belief, have no sufficient justification." $\mathrm{He}$ is of opinion, however, that in sea-water there is not much tendency to multiplication on the part of the typhoid bacillus, and the vitality of this organism is not indefinitely maintained there.

From another point of view the discharge of crude sewage into the open sea at low water mark, or into an estuary is important, especially if the tidal currents are not sufficiently strong to remove or dissipate the polluting matters without fear of their return, or of their deposition in dangerous proximity to the shore. In the case of an estuary the sewage may be carried to sea very slowly, and supposing it to be discharged on the ebb tide, it may be carried only a short distance before it is driven back by the flood, and so oscillate backwards and forwards, causing possibly a nuisance dangerous to health. As such conditions affect some of our chief watering-places they cannot be regarded with equanimity. I am, therefore, pleased to observe that this question has had the close consideration of the Royal Commission on Sewage Disposal, and in their fifth report they express the opinion "that unless the tidal currents are exceptionally strong and the volume of tidal water available for diluting the sewage is large in a given locality, the heavy solids of sewage and trade wastes should not be allowed to be discharged into tidal waters," and they also suggest that

* In experimental oysters inoculated with typhoid, the organism could be recovered from the body of the oyster up to the tenth day.

$t$ Dr. Bulstrode on oyster culture in relation to disease (Local Government Board twenty-fourth Annual Report.) no outfall should be permitted which discharges crude sewage at such a point that at low water the sewage flows either on to a stripped foreshore or into slack water.

\section{Isolition Hospitats Act.}

Soon after the County Sanitary Administration came into force, it was found that local authorities were inarlequately supplied in respect of hospital accommodation for isolating cases of infections disease. In 1892, the County Councils' Association promoted a Bill to make provisions for such hospitals. In the following year the Bill was amended, and nnder the able guidance of Lord Thring, it became law as the Isolation Hospitals Act, 1893, and county councils were empowered to establish in any of their districts an isolation hospital for the reception of patients suffering from infectious disease. The. initiative action can be taken by the county council in consequence of an application made to them by any local authority, urban or rural, or twenty-five or more ratepayers, or as a result of an inquiry made by the County Medical Officer of Health at their request. On the county council being satisfied as to the necessity of an isolation hospital, they may constitute a "hospital district," consisting of one or more local areas, and also a committee for the management of the hospital, composed of representatives of the sanitary authority or combined authorities, with the addition of members of the county council if thought fit. Power is given to the county council by Section 21, to contribute a capital or annual sum towards the structural and establishment expenses of an isolation hospital so provided, or to either class of such expenses, and by an amending Act passed in 1901, the county council may extend their contribution to any hospital established by a local authority under Section 131 of the Public Health Act, 1875. The question of contribution has been much discussed by county councils, and the methods adopted are by no means uniforn. In Cheshire, the council contribute to isolation hospitals, for which loans have been sanctioned, one-third the cost of site, buildings, and maintenance; to some districts retaining beds in hospitals, one-third of the annual cost; and to old hospitals, one-third annual cost of maintenance. The Derbyshire County Council pay one-fifth cost of construction, but this must not exceed $£ 40$ per bed; in addition, a grant of $£ 10$ per bed is made annually towards 
the establishment expenses. In Fssex, $£ 5$ per bed is paid to hospitals erected out of loans, and this contribution in 1907, amounted to about $£ 1,500$. In Northamptonshire, the council pay one-half of the establishment expenses of isolation hospitals, equivalent to about $£ 475$ per annum. In Lancashire, the difficulty in the way of making a fair and equitable contribution towards the isolation hospitals erected under the Public Health Act, 1875 , has decided the council to make no contribution, and as far as I am aware, the local committees are quite satisfied to carry out unaided their duties in regard to hospital provision. Other counties, for instance, Durham, Northumberland, Salop, West Riding of Yorkshire, Worcestershire, \&c., have, I believe, adopted a similar line of action.

By the application of judicions pressure, county. councils have been enabled to secure the hospital accommodation which was wanting previous to the passing of the Isolation Hospitals Act, and in regard to the County in which I serve, the majority of districts are now provided either directly with hospital accommodation, or have acquired the privilege of sending infected patients into hospitals provided by neighbouring authorities. Large combined districts have also been formed for the isolation of small-pox, and these have effected a great saving, with increased efficiency, as compared with the efforts of individual authorities. In Lancashire, the proportion of cases removed from hospital-provided districts varies considerably according to the disease and character of accommodation. The following table shows the cases of infectious disease, other than small-pox, treated in hospital as compared with home treatment during the five years, 1903-1907.

\begin{tabular}{|c|c|c|c|c|c|}
\hline Disease. & $\begin{array}{l}\text { Where } \\
\text { Treated. }\end{array}$ & Cases. & Deaths. & $\begin{array}{l}\text { MNortality } \\
\text { PerCent. }\end{array}$ & 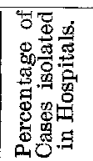 \\
\hline \multirow{2}{*}{ Scarlet Fever } & Hospital & 11,820 & 328 & $2 \cdot 7$ & \multirow{4}{*}{$\begin{array}{l}\{29 \cdot 8 \\
\{16 \cdot 4\end{array}$} \\
\hline & Home & 27,739 & 981 & $3 \cdot 5$ & \\
\hline \multirow{2}{*}{ Diphtheria } & Hospital & 1,398 & 161 & $11 \cdot 5$ & \\
\hline & Home & 7,126 & 1,346 & $18 \cdot 8$ & \\
\hline Enteric & Hospital & 1,860 & 355 & $19 \cdot 0$ & \multirow{2}{*}{\} $30 \cdot 2$} \\
\hline Fever. & Home & 4,296 & 826 & $19 \cdot 2$ & \\
\hline
\end{tabular}

Although I do not propose to enter into the controversy as to the utility of isolating scarlet fever, which was started by Dr. Wilson, of Lanarkshire, in 1897, and has attracted the attention of several well-known members of our Society, I must say that as far as my experience goes, a scarlet fever patient has a better chance of lecovery in a properly constituted hospital, than in the ordinary cottage home, and I know how much removal is appreciated by the public at large, whether engáged in business or otherwise, and I may say also by the patients themselves. I quite agree that the hospital isolation of scarlet fever, has not quite answered expectations in regard to the curtailment of disease, but at the same time, no efficient sanitary authority can do without it. The non-removal policy, I always look upon as possessed of many attractions for parsimonious authorities, but to my mind, it seems very selfish to endanger the health of neighbouring districts, while engaged in the hopeless attempt to procure isolation in the ordinary dwellings of the working class.

\section{Provision of Sanatoria for the Treatment of Consumptives.}

Under the Isolation Hospitals Act, as already mentioned, a county council may constitute a committee to provide hospital accommodation for patients suffering from infectious diseases, i.e., from those specified in the Infectious Diseases (Notification) Act, 1889, while under Section 26 of the Isolation Hospitals Act, 1893, the term "infectious diseases" may be applied to any other disease such as pulmonary tuberculosis, by order of the County Council with the consent of the Local Government Board. In such an order the county council may form a hospital committee or committees, under the Isolation Hospitals Act, for the specific purpose of providing hospital accommodation for consumptives, and may contribute towards the cost or maintenance of such hospital. The hospital committee have power, under Section 3 of the Isolation Hospitals Act, 1901, to enter into agreement with local authorities for the use of the whole or part of a hospital for the reception of their patients, and defray the expenses of such accommodation. There is therefore ample power on the part of county councils to erect or to purchase sanatoria, to contribute to the maintenance of patients in such establishments, and within certain limits to compulsorily combine sanitary authorities for the purpose of providing 
sanatoria. It appears that, so far, Devonshire and Cheshire are the only counties which have added pulmonary tuberculosis to the list of "infectious diseases," but no special accommodation has yet been provided out of the county funds; in the counties of Durham, Westmoreland and Worcester some provision has been made by guardians, district councils, etc., by adapting pre-existing buildings for treating consumptives, and the boards of guardians of the city of Liverpool have combined for the erection of a permanent sanatorium at Heswell on the banks of the river Dee. Dr. Bulstrode reports favourably to the Local Government Board as to the value of sanatorium treatment in pulmonary tuberculosis." As far as the "immediate result to the individual" is concerned, he believes the best results are obtained when the patients are admitted to treatment in the earlier stages of their malady, but as to "after results," that is the remoter benefit referable to sanatorium treatment, he hesitates to give an opinion.

\section{Housing of the Working Classes.}

The problem relating to the suitable housing of the working classes is one of great difficulty in many towns with congested populations, and to a less degree in the small urban districts and rural areas. Since Torrens's Act, in 1868, and Cross's Acts in 1875 and 1879, for providing better dwellings for artisans and labourers became law, the desire on the part of legislature to improve the housing of the industrial portion of the community has resulted in several Acts of Parliament-commencing with the Housing of the Working Classes Act, 1885-being passed with this object in view. At the present time the increasing facilities for rapid locomoticn has created a strong disposition on the part of the inhabitants of towns to reside in the rural districts, and in order to make provision for this overflow the President of the Local Government Board, in his Housing, Town Planning, ete., Bill now before Parliament, proposes to give assistance to adequate schemes devised "with the general object of securing proper sanitary conditions, amenity and convenience in connection with the laying out and use of the land." In the promotion of the new schemes, efficient control will be substituted for chance which has

Loeal Govermment Board Report, 1905-6, Ur. Bulstrode on Sanatovia for Consumptives \&c. played such an inportant part in the town formation of the past, and local authorities will be able to promote schemes, not only in their own areas, but in the areas of ncighbonring authorities, and also associate themselves with the authority responsible for the local administration of public health, etc. It seems to ine reasonable to suggest that in any townplanuing scheme within an administrative county area, the county council should be included, and they should play an important part in determining how the land shomld be laid ont, the width and direction of the main arteries of traffic, the sewerage and sewage lisposal, etc. Unless these matters are satisfactory to the county authority, difficulties will arise that would be better avoided at the initial stage of the scheme. As far as Iancashire is concerned, except in certain boroughs and large urban districts such as Darwen (B), Eccles (B), Ormskirk, Prescot, Stretford, etc., very inadequate action has taken place under the acts relating to the housing of the working classes, and in respect of rural districts practically nothing has been done in this direction, and no application has been received by the county council under Section 2 of the Housing of the Working Classes Act, 1900 , to adopt Part IJI. of the principal Act.* The latter Act was primarily intended to cope with the evils in towns, and only inciclentally intended to apply to rural districts. Much overcrowding is, I believe, caused by a lack of house accommodation in villages, and houses are in consequence allowed to be occupied, although unfit for habitation. The water supply is frequently polluted and the drainage defective, and I quite agree with Mr. Wilson Fox $t$ that in rural districts cottages are sometimes empty on account of there being no water within a reasonable distance; whilst there are many villages where the water supply is not only deficient in quantity, but bad in quality, thereby causing unhealthy conditions and hardship to the occupier. By Clause 2 of the Bill promoted by Mr. Burns, power is given to the Local Government Board to declare that a local authority has failed to exercise their powers under Part 3 of the principal Act, and the Board can "make an order directing that authority, or if the Board think fit, in any case where the authority in default is the council of a county

The Housing of the Working Classes Act, 1890.

t Report of Solect Committee on Housing of the Working Classes Acts Amendment Bill, 1906. 
district, the county council," to carry out the work required to be done. By further complicated procedure, to be initiated by the Local Government Board, it is proposed to make sure of the execution of the Honsing Acts by the authorities concerned; but I do not think such power will ever be put in force, or would prove successful in operation. In housing legislation, procedure should be simplified, and the county council might with confidence be given power to carry out any new duties without the sword of Damocles in the form of a Local Government Board mandamus being constantly held over them.

\section{Midwives Aơt, 1902.}

Probably the most important sanitary duty that county councils have to perform is that of administering the Midwives Act, 1902. Its importance cannot be over-estimated, for it concerns the lives and health of mother's and new-born infants, and affects most intimately the former, especially if in their parturient condition, they should be in want of the means for securing the professional care and attention so much needed. From the Registrar-General's report it appears that in 1906 there were recorded in England and Wales 1,640 deaths of women from puerperal septic diseases, and 2,117 from other diseases of pregnancy or of childbirth, together amounting to 3,757 , and equivalent to a rate of 4.02 per 1,000 births. In the ten years immediately preceding, the average proportion had been $4 \cdot 48$ per 1,000 . 'To this large mortality from child-bed illness, half of which at least is capable of prevention, there must be added, according to Sir James W. Byer's, of Belfast, "the further incalculable loss from secondary gynæcological disease, and sterility entailed by slighter and not immediately fatal cases of infection." In discussing the amount of morbidity, Sir Wm. J. Sinclair, in a valuable paper read before the North-Western Branch of the Society, stated that for every fatal case of puerperal fever there are at least five, six, or seven cases of child-bed morbidity which cause chronic ailments and produce in some measure continuous suffering and prolonged or permanent disablement. By the adoption of strict hygienic measures, it has been amply shown by him that puerperal infection may be considerably reduced. Among many instances, I may mention that in 1880 , one-half of the women confined within the Rotunda Hospital (Dublin) suffered from puerperal fever; while in 1905 of 1,887 cases the percentage of morbidity was only 8.42 , without a single death.* Dr. Boxall reported in 1905 that 8,373 cases had been attended in the General Lying-in Hospital (London), "and not one deatll from sepsis originated in the hospital in the course of sixteen years." It would appear that in many of the continental towns the results of home treatment, judged by the amount of mortality and morbidity from childbed diseases, are nearly as successful as in the lying-in hospitals; but it must be remembered that the midwives are better trained than in this country, and under more rigid supervision. In England and Wales during 1906, the mortality at child-birth from pnerperal septic disease was equal to 1.7 per 1,000 births, indicating to my mind a proportion of deaths which might be much reduced by the strict enforcement of antisepsis and asepsis, and by less interference on the part of those in attendance with the course of natural labour. In Lancashire, 811 midwives attended last year 21,583 , or practically half the county births, with the occurrence, so far as can be ascertained, of 25 puerperal fever deaths equal to 1.15 per 1,000 births; while as a result of 21,558 births attended by other than certified midwives, 42 women died from puerperal fever, equivalent to 1.94 per 1,000 births. These facts are difficult to explain, but I am inclined to believe that certified midwives, with all their faults, are not responsible for an undue share in the dissemination of puerperal infection. It is very difficult to obtain correct information on this subject, as notification with respect to puerperal fever is imperfectly carried out, and even death certificates are not always free from ambiguity. This uncertainty will continue until the Notification of Births Act, 1907, is generally adopted, and exact knowledge of births is rendered available for local supervising authorities. By Section 2 the council of a county may adopt the Act either for the whole county or for any connty district, and pay the expenses incident to its enforcement, but as far as I am aware the only county $\dagger$ that has taken practical action in

\footnotetext{
* Report by Dr. Tweedy, Master of the Rotunda Hospital for 1905.
}

+ The Leicestershire County Council have recently applied to the county but the B Board for consent to adopt the Act for the whole district councils should have an opportunity of adoptiug the Act. 
this direction is Durham, where health visitors have been recently appointed at the county expense to carry out their duties in three specially selected districts in which the infant mortality is unduly high.

Time at my disposal will not allow me to discuss the many interesting and important details respecting the administration of the Midwives Act. I may, however, express my opinion that it has initiated a most valuable work in this country, which month by month is attaining greater perfection. The rules of the Central Midwives Board have lately been subjected to most careful revision, and expelience shows that they are being administered with great efficiency, and that a vast improvement has been effected in the character and methods of midwives generally. It is also pleasing to note from the reports that are periodically presented to local supervising authorities in various parts of the country, that even the illiterate midwives are being educated to perform more satisfactorily their duties. To fill the gaps that are constantly taking place in the ranks of the bonâ fide midwives, it is hoped that better trained women will be available, and perhaps some of the supervising authorities may find it necessary, in order to make provision for their possible needs in the near future, to offer suitable persons some inducement to take up this important work.

\section{Food Adulteration.}

The only other subject I have to refer to at any length is that of food adulteration. On the passing of the Local Government Act, Lancashire and other counties took over from the county magistrates the administration of the Sale of Food and Drugs Act, 1875, and continued the appointments of members of the police force, usually the superintendents, as inspectors under the Act, with the subsequent addition in some instances of special inspectors. Certain county councils appear to have made arrangements with the sanitary inspectors of district councils to purchase samples, but in 1902, on the question being raised, by way of surcharge on audit, as to whether a county council could employ officials not acting under their direction, some modification of the system took place. The number of samples purchased for analysis in the large counties, as shown. in the following tabulated statement, " varies considerably, and there is also great variation in the percentage of adulteration.

Sauples Ptrchased under the Sale of Food axd Drugs Acts nuring the Five Years, 1903-1907.

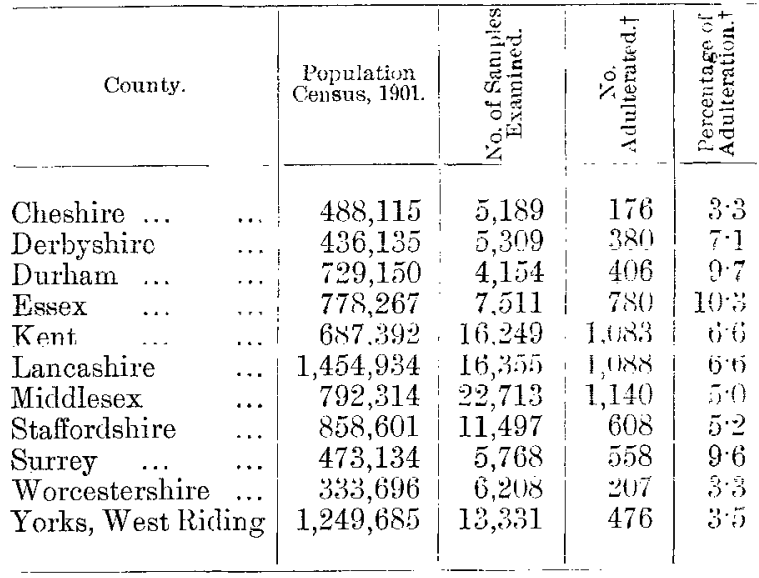

t The word "adulterated" implies that the sanple was not certified by the prublic analyst as genuine, and does not imply that any person was convicted of an offence.

It is impossible to explain the difference in the amount of county adulteration without knowing the particulars as to the mode of procedure in purchasing samples, and the character and number of the articles purchised in accordance with the Act, or as "test" samples, i.e., without formalities. Of course, it is quite easy to understand that where vigorous action is taken in a district, there will be a tendency for adulteration to remain in abeyance; for example, I may mention that in 1904 it was not an uncommon practice for shops to be opened in the manufacturing districts of Lancashire by fraudulent traders, who posed as Irish egg and butter merchants, and advertised largely their butter at considerably less than market price. Test samples of the butter on being analysed were found to be margarine, and on the police becoming satisfied of the fraudulent nature of the business, they took the persons engaged in it into custody, with the result that three of them were found guilty at the Manchester Quarter Sessions of obtaining money under false pretences, and sentenced to twelve months' hard labour: As might be expected, these convictions induced the remaining members of the gang to seek districts more favourable for their nefarious operations. Another instance may be given of the stoppage of an extensive sale, in Lancashire, of pepper, adulterated with ground olive stones and bleached husks. The following are facts of this case:-November 24th,

* Local Government Buard Annual Reports, 1903-1907. 
1903, sample of pepper purchased Newhey (Co-operative Society), was certified to contain 8 per cent. of olive stones. January $6 \mathrm{th}, 1904$, society summoned under Section 6, Sale of Food and Drugs Act. Case dismissed on production of warranty from Messrs. S. \& J. R., Manchester, who had supplied a keg of pepper direct from the grinder, C. J. Therefure the pepper in question never came into the hands of Messrs. R. at all, although they received a guarantee from C. J. as to its purity. An information was therefore laid by Messrs. R. (on behalf of the County Authority) against C. J., under the Merchandise Marks Act, 1887, for having applied a false trade description to goods. On June 16th, 1904, C. J. was tried before the Liverpool City stipendary (Mr. Stewart), and sent to prison for three months without the option of a fine. Before the case was heard, Mr. Stewart granted a search-warrant upon the works of C. J., and eleven lurry loads of ground olive stones, bleached and unbleached pepper husks, and adulterated pepper, were removed from the premises by the police and afterwards destroyed. On leaving prison, C. J. gave up a very lucrative business and left the country.

I find on looking, through the samples purchased in Lancashire since the passing of the Sale of Food and Drugs Acts that there has been a gradual decline in the total amount of adulteration, from 19.5 the average percentage from 1876-1881 to $6 \cdot 6$ from $1903-1907$. The following table shows that during the last five years the adulteration of butter and miscellaneous articles has declined in Lancashire, but no practical improvement has taken place as regards milk.

Percentage of Offences.

Lancashire Administrative Area.

\begin{tabular}{c|c|c|c}
\hline Year. & Milk. & Butter. & $\begin{array}{c}\text { Mizcellaneous } \\
\text { Articles. }\end{array}$ \\
\hline 1903 & $7 \cdot 2$ & $5 \cdot 8$ & $8 \cdot 0$ \\
1904 & $7 \cdot 2$ & $7 \cdot 3$ & $7 \cdot 2$ \\
1905 & $8 \cdot 3$ & $4 \cdot 9$ & $5 \cdot 0$ \\
1906 & $9 \cdot 6$ & $2 \cdot 1$ & $3 \cdot 9$ \\
1907 & $7 \cdot 0$ & $2 \cdot 3$ & 28 \\
\hline
\end{tabular}

After the long experience in this country of the working of Acts passed with the object of preventing food adulteration, it is surely a reflection on the Government that milk, the most important article of food so far as the infant is concerned, still continues to be subjected to such frequent adulteration. The reason to some extent may be due to the simplicity of this form of adulteration, and the attractive convenience of the "cow with the iron tail" proving too tempting for the dishonest milk dealer to resist. The standard set up by the Board of Agriculture under Section 4 of the Sale of Food and Drugs Act, 1899, is a good one in my opinion, but its value is largely neutralised, as it merely raises "a presumption until the contrary is proved" that the article is not genuine. I regret to say that it is becoming increasingly difficult to obtain convictions in any case of alleged milk adulteration, and occasionally cases are even dismissed by the magistrates, although there may be practically no evidence for the defence. In order to avoid these difficulties $I$ quite agree with the iclea that there should be a fixed universal standard of genuineness below which the sale of milk should be probibited. A resolution in agreement with this view was passed by the Council of Municipal Corporations in July, 1907; and in the report of the Board of Agriculture and Fisheries, for the same year, I find it stated that "there is much to be said in favour of a universal standard, and if the prohibition against the sale of milk below the standard adopted applied to wholesale as well as retail transactions, it would certainly be convenient that the standard should be universal, so that farmers sending milk into different districts should know that the milk would be treated alike wherever it was sent." With respect to the prosecutions for the use of preservatives, the practice in the various courts differs considerably, and in order to produce uniformity of action, the Board of Agriculture should not further delay the making of regulations as to preservatives in accordance with the recommendations of the Departmental Committee. As far as milk is concerned, there ought to be no difficulty, for the committee recommended that the use of any preservative or colouring matter whatever in milk offered for sale in the United Kingdom be constituted an offence under the Sale of Food and Drugs Act.

By the enforcement of the Butter and Margarine Act, 1907, fraudulent blenders of butter will find it more difficult to continue their profitable system of adulteration, as now premises used for the blending or re-working 
of butter have to be licensed and-subject to inspection. Previous to the passing of this Act, there were certain large butter blenders making annually considerable sums of money, representing thousands of pounds, by the scientific sophistication of butter. Their mode of procedure was to mix with butter, say 20 per cent. of a neutral fat difficult for the analyst to identify called "lardine," and in some cases they used certain proportions of cocoa-nut oil and specially prepared animal fats, the object being to obtain a mixture of fats which would have approximately the same iodine number and refractive index as ordinary butter. An interesting prosecution for this form of adulteration, and one showing the difficulty, and expense of pursuing adulteration to its source, was successfully conducted by the Lancashire County Council in 1905, under the Merchandise Marks Act, the wrongdoers being followed from Radcliffe to their place of business in the City of London. On an information laid against Messrs. C. \& Y. (the fraudulent firm) at the Clerkenwell Police Court, a search-warrant was granted, and on being executed a large quantity of goods were seized and found to be adulterated. After several days hearing, the stipendary in one case fined Messrs. C. \& Y. $£ 20$ and $£ 250$ towards the costs of the County Council, and in another $£ 5$ and $£ 5210$ s. 0d. costs. Much of the trouble experienced in running to earth the chief offenders in this case will be in future avoided by the operation of the legislation already mentioned.

In my remarks, which I trust have not proved wearisome, I have endeavoured to explain the powers of county councils in regard to health administration, and to show that with increasing confidence fresh duties are being constantly added by legislature. Great attention is now being directed to new and vastly important duties provided by the Education (Administrative Provisions) Act, 1907 , in respect of the medical inspection of the school children, and I regret that I cannot speak with any authority on this subject at the present time; but I fully believe that this new legislation will attain its aim in effecting an improvement in the health and physique of the present generation, and " as a natural corollary, the mental and moral improvement of coming generations."

\section{THE DEVELOPMENT OF PUBLIC HEALTH WORK.:}

By R. E. I AUDER, M.D., F.R.C.S.,

Medical Officer of Health, Borough and Port of Southampton.

PROPOSE to-day to review briefly the hiatory of the development of public health work, including therein its latest phasethe medical inspection of elementary school children.

The latter being a suljjuct of paranum importance, and of such a complex nature, it behoves those responsible for its a Mministration to consider it at every available opportmity.

By briefly reviewing the duties of the medical officer of health in the past with his duties to-day, we shall be in a position to appreciate the possible extensions of the future, ancl the way they are liable to be modified by recent legislation.

With the commencement of the reign of Queen Victoria might be said to have begm the dawn of public health work.

A Royal Commission was appointed in 1833 to examine into the treatment of chilclren in factories, and the report of that Commission led to the passing of the Poor Taw Amenrlment Act, and the creation of a Central Administrative Commission for the purposes of the Act. In 1838 the Poor Law Commission drew the attention of the Home Secretary to the large amount of preventable diseases existing, which they considered, cansed pauperism.

In the following March, the House of Commons appointed a Select Committee "to inquire into the circumstances affecting the health of the inhabitants of large towns, with a view to improve sanitary arrangements for their benefit."

Three months later, this Committee reported :-

(1). That there ought to be a General Buildings' Act.

(2). That there ought to be a General Sewage Act.

(3). That in every town of a certain population there ought to lue a standing Board of Health, which should observe the health of the town, should move the local commissioners of sewers or other

*Read at Meeting of Southern Branch of the Society of Medical Officers of Health, September 24 th, 1908 